\title{
Quality characteristics and antioxidant activity of Sulgidduk added with maquiberry powder
}

\author{
Namsook Cho, Hai-Jung Chung* \\ Department of Food Science and Nutrition, Daejin University, Pocheon 11159, Korea
}

마키베리 분말 첨가 설기떡의 품질특성 및 항산화 활성

\author{
조남숙·정해정* \\ 대진대학교 식품영양학과
}

\begin{abstract}
This study was carried out to investigate the quality characteristics and antioxidant activity of Sulgidduk (oriental-style rice cakes) prepared with different amounts $(0 \%, 2 \%, 4 \%$, or $6 \%$ ) of maquiberry (Aristotelia chilensis) powder. The moisture content of treated Sulgidduk ranged from $37.75 \%$ to $38.79 \%$, with no significant differences between treatment groups. The $\mathrm{pH}$ gradually decreased with the increasie in maquiberry powder. The soluble solid content did not show significant differences between groups. The lightness $(L)$ value decreased, while redness (a) value increased with the increase in added maquiberry powder. Hardness of the control group was lower than those of the treatment groups. Consumer acceptance test results revealed no significant differences in smell, taste and overall acceptability scores. The total polyphenol and total anthocyanin contents were 8.66 262.71 $\mathrm{mg} \mathrm{GAE} / 100 \mathrm{~g}$ amd $0.01 \sim 9.76 \mathrm{mg} \mathrm{C3G} / 100 \mathrm{~g}$ ), respectively. Moreover, the polyphenol and anthocyanin levels increased with increasing levels of added maquiberry powder. In addition. reducing power and 1,1-diphenyl-2-picrylhydrazyl (DPPH) and 2,2'-azino-bis (3-ethylbenzothiazoline-6-sulfonic acid) (ABTS) radical scavenging activities significantly increased with increase in added maquibery powder. Based on the above results, addition up to $6 \%$ maquiberry powder incorporated into Sulgidduk will meet the taste and functional needs for consumers.
\end{abstract}

Key words : Sulgidduk, maquiberry, quality, characteristics, antioxidant

\section{서 론}

떡은 우리나라 고유의 곡물요리로서 그 종류가 수십 수 백 종에 이르지만 조리방법으로 분류하면 찐 떡, 친 떡, 지진 떡, 삶은 떡으로 구분한다(1). 그 중 백설기는 찌는 떡의 가장 기본이 되는 것으로 흰무리라고도 하는데 멥쌀가 루에 물을 내려서 한 덩어리가 되게 찌는 떡이며 아무 것도 섞지 않은 흰 색깔이 순수하고 신성한 의미를 주어 의례나 행사에 쓰이는 대표적인 음식이다 $(1,2)$. 시대가 변화함에

*Corresponding author. E-mail : haijung@daejin.ac.kr

Phone : 82-31-539-1861, Fax : 82-31-539-1860

Received 20 July 2016; Revised 11 October 2016; Accepted 31 October 2016.

Copyright (c) The Korean Society of Food Preservation. All rights reserved.
따라 최근 식품의 소비 경향은 건강증진, 항노화, 질병의 방지와 회복 등의 생리활성을 강화한 식품으로 이어지고 있다. 아울러 식품의 미적 요소인 색감에 대한 요구도 높아 지고 있어서(3) 설기떡의 경우에도 소비자의 요구와 기호를 고려하여 다양한 부재료를 첨가한 제품개발 연구가 활발히 진행되고 있다. 선행 연구로는 아스파라거스 분말(4), 아로 니아 분말(5), 아사이베리 분말(6), 울금 분말(7), 복분자 잎 분말(8), 비트잎 가루(9), 가지 분말(10)을 첨가한 설기떡 연구 등이 보고된 바 있다.

농산물 시장 개방 이후 과일의 소비 트렌드가 변화하면 서 가장 빠르게 자리잡은 과일이 바로 베리(berry)류이다. 작지만 비싼 과일로 알려진 베리류는 독특한 색과 맛을 지닐 뿐만 아니라 기능성 물질이 함유된 것으로 알려져 인기를 끌면서, 딸기가 주종을 이루던 국내 시장에는 블루 베리, 라스베리, 크랜베리, 아사이베리, 아로니아 등 다양한 
종류가 시판되고 있으며 수입량도 빠르게 증가하고 있다. 실제로 블루베리 냉동과의 수입량은 2011년에 7,291톤이던 것이 2014년에는 12,012 톤으로 $64.8 \%$ 가 증가하였고 생과 의 수입량은 2012년 320톤에서 2014년에는 1,275톤으로 $298 \%$ 가 증가한 것으로 보고되었다(11). 블루베리와 흡사한 모양을 지닌 마키베리(maquiberry, Aristotelia chilensis)는 칠레의 중남부지역과 아르헨티나 서부지역에서만 자생하 는 식물의 열매로 칠레에서는 예로부터 식용뿐 만 아니라 약용으로 사용하여 인후염, 궤양, 열병, 염증, 설사 등의 민간요법에 이용되어 왔다 $(12,13)$. 마키베리는 phenolic acid, tannin, flavonoid 등 폴리페놀이 풍부하고 특히 안토시 아닌이 다량 함유되어 있어 항산화작용이 가장 강력한 베리 중의 하나로 알려져 있으며 그 외에도 지질생성 억제, 항염, 항당뇨, 항균 등의 효과가 있는 것으로 보고되고 있다 (12-15). 이에 본 연구에서는 안토시아닌 색소를 다량 함유 하고 있을 뿐 만 아니라 생리활성이 우수한 마키베리를 이용하여 설기떡을 제조하고 품질특성과 항산화 활성을 살펴봄으로써 건강지향적인 간식 또는 후식으로서 마키베 리 설기떡의 이용가능성에 대해 평가하고자 하였다.

\section{재료 및 방법}

\section{재 료}

설기떡 제조에 사용된 멥쌀은 강원도 철원산, 마키베리 분말은 칠레산을 2015년 11월에 각각 구입하였고 그 외 백설탕(CJ, Incheon, Korea), 소금(Hanju Co., Ulsan, Korea) 은 시중에서 구입하였으며 물은 증류수를 사용하였다.

\section{설기떡의 제조}

멥쌀은 4회 세척하고 상온에서 8시간 수침한 후 체에 받쳐 30 분간 물빼기를 한 후 분쇄하여 $20 \mathrm{mesh}$ 체에 내리고 polyethylene bag에 담아 탈기밀봉한 후 $-20^{\circ} \mathrm{C}$ 에 냉동보관하 며 사용하였다. 마키베리 첨가 설기떡은 예비 실험을 거친 후 Table 1과 같이 배합비율을 정하여 멥쌀가루 대비 마키

Table 1. Ingredients of Sulgidduk added with maquiberry powder

\begin{tabular}{ccccc}
\hline \multirow{2}{*}{ Ingredients } & \multicolumn{4}{c}{ Groups $^{1)}$} \\
\cline { 2 - 5 } & S-0 & S-2 & S-4 & S-6 \\
\hline Rice flour (g) & 100 & 98 & 96 & 94 \\
Maquiberry powder (g) & 0 & 2 & 4 & 6 \\
Sugar (g) & 15 & 15 & 15 & 15 \\
Salt (g) & 0.8 & 0.8 & 0.8 & 0.8 \\
Water (mL) & 18 & 18 & 18 & 18 \\
\hline
\end{tabular}

${ }^{1)} \mathrm{S}-0$, Sulgidduk with maquiberry powder $0 \%$; S-2, Sulgidduk with maquiberry powder $2 \%$; S-4, Sulgidduk with maquiberry powder $4 \%$; S-6, Sulgidduk with maquiberry
powder $6 \%$.
베리 분말 첨가량을 $0 \%, 2 \%, 4 \%, 6 \%$ 로 첨가하여 제조하였 다(16). 멥쌀가루, 마키베리 분말, 소금, 설탕, 물을 넣고 잘 섞은 다음 20 mesh 체에 2 번 통과시켰다. 찜솥에 면보를 깔고 stainless steel 사각틀(가로 $12 \mathrm{~cm} \times$ 세로 $12 \mathrm{~cm} \times$ 높이 $5 \mathrm{~cm}$ )에 시료를 담아 윗면을 편편하게 고르고 $3 \mathrm{~cm} \times 3 \mathrm{~cm}$ 크기로 칼집을 넣은 후 면보를 덮어 김이 오른 찜통에서 25 분간 찌고 10 분간 뜸을 들인 다음 실온에서 1 시간 방냉한 후 실험에 사용하였다.

\section{수분함량, $\mathrm{pH}$ 및 당도 측정 측정}

마키베리 분말 첨가 설기떡의 수분 함량은 상압가열 건 조법(17)으로 분석하였다. 설기떡의 $\mathrm{pH}$ 는 설기떡 $1 \mathrm{~g}$ 에 증 류수 $20 \mathrm{~mL}$ 를 넣고 균질화하여 $5,000 \mathrm{rpm}$ 에서 30 분간 원심 분리하여 얻은 상층액을 $\mathrm{pH}$ meter(InoLab, Weilheim, Germany)로 측정하였다. 당도는 설기떡 $1 \mathrm{~g}$ 에 증류수 10 $\mathrm{mL}$ 를 가하여 균질화한 다음 $5,000 \mathrm{rpm}$ 에서 20 분간 원심분 리하여 얻은 상층액을 당도계(Atago PR-101a, Atago Co., Tokyo, Japan)로 측정하여 ${ }^{\circ} \mathrm{Brix}$ 로 표시하였다.

\section{색도 측정}

설기떡의 색도는 색차계(JX 777, Juki, Tokyo, Japan)를 이용하여 명도(L, lightness), 적색도(a, redness), 황색도(b, yellowness)값을 측정하였고 한 처리군당 세 개의 시료를 사용하였으며 한 시료 당 측정 위치를 각각 달리하여 2회 반복 측정하여 평균값으로 나타내었다.

\section{기계적 조직감 측정}

설기떡의 조직감은 시료를 $3 \mathrm{~cm} \times 3 \mathrm{~cm} \times 3 \mathrm{~cm}$ 로 잘라 Rheometer(Compac-100, Sun Scientific Co., Tokyo, Japan)를 사용하여 경도(hardness), 응집성(cohesiveness), 탄력성 (springiness), 씹힘성(chewiness) 등을 측정하였다. 각 처리 군당 여섯 개의 시료를 사용하여 평균치로 표시하였다. 측 정에 사용된 조건은 test type: mastication, load cell: $10 \mathrm{~kg}$, adaptor type: round(diameter $10 \mathrm{~mm}$ ), table speed: 120 $\mathrm{min} / \mathrm{min}$ 이었다.

\section{기호도 검사}

설기떡의 기호도 검사는 훈련받지 않은 식품영양학과 학생 20 명을 대상으로 실시하였다. 일정한 크기로 설기떡 을 잘라 임의의 3 자리 숫자로 각각 표기하여 흰 접시에 담아 제공하였고 평가항목은 표면색(surface color), 냄새 (smell), 맛(taste), 전체적인 기호도(overall acceptability) 등 을 7점 항목 척도법(1점, 매우 싫다; 2점, 보통으로 싫다; 3점, 약간 싫다; 4점, 좋지도 싫지도 않다; 5 점, 약간 좋다; 6점, 보통으로 좋다; 7점, 매우 좋다)을 사용하여 평가하 였다. 


\section{총 폴리페놀 및 총 안토시아닌 함량 측정}

총 폴리페놀 및 총 안토시아닌 함량 측정을 위한 시료로 는 설기떡 $5 \mathrm{~g}$ 에 methanol $150 \mathrm{~mL}$ 를 가하여 실온에서 2시간 진탕 교반한 후 $4,000 \mathrm{rpm}$ 에서 30 분간 원심분리하여 얻은 상층액을 사용하였다. 총 폴리페놀 함량은 Dewanto 등(18) 의 방법을 일부 변형하여 시료 $0.1 \mathrm{~mL}$ 에 $1.9 \mathrm{~mL}$ 의 증류수와 Folin-Ciocalteu's phenol reagent $0.2 \mathrm{~mL}$ 를 가한 후 실온에서 3 분간 방치하고 포화 sodium carbonate 용액 $0.4 \mathrm{~mL}$ 를 가하 여 혼합한 후 다시 $1.9 \mathrm{~mL}$ 의 증류수를 첨가하였다. 이 혼합 액을 실온에서 1시간 동안 반응시킨 후 $725 \mathrm{~nm}$ 에서 흡광도 를 측정하였다. 표준물질로는 gallic acid를 이용하여 표준 곡선을 작성한 후 mg gallic acid equivalents(GAE)/g으로 나타내었다.

총 안토시아닌 함량은 Lee 등(19)의 방법에 준하여 측정 하였다. 즉, 시료용액 $1 \mathrm{~mL}$ 에 $0.025 \mathrm{M}$ potassium chloride buffer(pH 1.0)와 $0.4 \mathrm{M}$ sodium acetate buffer $(\mathrm{pH} 4.5)$ 를 각각 가하여 최종 부피를 $5 \mathrm{~mL}$ 로 한 다음 510 및 $700 \mathrm{~nm}$ 에서 흡광도를 각각 측정하고 아래의 식으로 계산하여 $\mathrm{C} 3 \mathrm{G}$ (Cyanidin-3-glucoside)로 나타내었다.

안토시아닌 함량(cyanidin-3-glucoside equivalents, $\mathrm{mg} / \mathrm{L}$ )= $\frac{\mathrm{A} \times \mathrm{MW} \times \mathrm{DF} \times 103}{\varepsilon \times 1}$

$\mathrm{A}($ absorbance value $)=\left(\mathrm{A}_{510} \mathrm{~mm}-\mathrm{A}_{700 \mathrm{~mm}}\right) \mathrm{pH}$ 1.0-( $\left(\mathrm{A}_{510} \mathrm{~mm}-\mathrm{A}_{700 \mathrm{~mm}}\right)_{\mathrm{pH}} 4.5$ $\mathrm{MW}$ (molecular weight of cyanidin-3-glucoside) $=449.2 \mathrm{~g} / \mathrm{mol}$ $\mathrm{DF}$ (dilution factor)=dilution ratio of sample $\varepsilon$ (cyanidin-3-glucoside molar absorbance) $=26,900$ molar

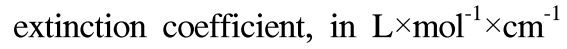

$l=$ pathlength in $\mathrm{cm}$

\section{항산화 활성 측정}

설기떡의 항산화 활성을 측정하기 위해서는 총 폴리페놀 함량 측정에서와 동일한 방법으로 제조된 시료 용액을 사용 하였다. DPPH(1,1-diphenyl-2-picrylhydrazyl) radical 소거 능 측정은 Blois(20)의 방법에 준하여 시료 용액 $0.1 \mathrm{~mL}$ 에 $\mathrm{DPPH}$ 용액 $\left(1.0 \times 10^{-4} \mathrm{M}\right) 1.9 \mathrm{~mL}$ 를 가하여 교반하고 실온에 서 30 분간 반응시킨 후 $517 \mathrm{~nm}$ 에서 흡광도를 측정하여 시료용액 첨가군과 무첨가군 간의 흡광도 비(\%)로 나타내 었다.

ABTS(2,2'-azino-bis(3-ethylbenzothiazoline-6-sulfonic acid) radical 소거능은 Re 등(21)의 방법을 일부 수정하여 측정하였다. 즉, $\mathrm{ABTS}$ 용액과 $2.45 \mathrm{mM}$ potassium persulfate 를 14:1로 혼합(v/v)하여 실온의 암소에서 20시간 방치한 후 증류수를 가하여 $734 \mathrm{~nm}$ 에서의 흡광도값이 0.70 내외가 되도록 희석하였다. 이 중 $2 \mathrm{~mL}$ 를 취하여 시료용액 0.02 $\mathrm{mL}$ 와 혼합하고 실온에서 5 분간 방치한 다음 $734 \mathrm{~nm}$ 에서
흡광도를 측정하여 시료용액 첨가군과 무첨가군 간의 흡광 도 비(\%)로 나타내었다.

환원력 측정은 Wong과 Chye(22)의 방법을 일부 변형하 여 측정하였다. 시료 용액 $1.0 \mathrm{~mL}$ 에 $0.2 \mathrm{M}$ phosphate buffer(pH 6.6) $2.5 \mathrm{~mL}$ 와 $1 \%$ potassium ferricyanide $2.5 \mathrm{~mL}$ 를 가하여 잘 혼합하고 $50^{\circ} \mathrm{C}$ 에서 20 분간 반응시켰다. 이를 실 온으로 냉각시킨 후 $10 \% \mathrm{TCA}$ 용액 $1 \mathrm{~mL}$ 를 가하여 혼합하 고 이 중 $1.0 \mathrm{~mL}$ 를 취해 증류수 $1 \mathrm{~mL}$ 와 $0.1 \% \mathrm{FeCl} 30.5$ $\mathrm{mL}$ 를 가한 다음 실온에서 10 분간 방치한 후 $700 \mathrm{~nm}$ 에서 흡광도를 측정하였다.

\section{통계처리}

모든 실험은 3회 이상 반복 측정하였고 자료 분석은 SPSS(Verion 22.0 for windows, SPSS Inc.)를 이용하여 평균 \pm 표준편차를 구하였으며 분산분석(ANOVA)과 Duncan's multiple range test를 실시하여 $\mathrm{p}<0.05$ 수준에서 시료 간 유의적인 차이를 검증하였다.

\section{결과 및 고찰}

\section{수분함량, $\mathrm{pH}$ 및 당도}

마키베리 분말 첨가 설기떡의 수분함량, $\mathrm{pH}$, 당도 측정 결과는 Table 2 와 같다. 수분함량은 대조군이 $38.79 \%$, 첨가 군이 $37.75 ~ 38.06 \%$ 로 모든 시료 간에 유의적인 차이가 없 었다. 이러한 결과는 청국장가루 첨가 설기떡(23)의 연구에 서 청국장 가루 첨가량에 따라 수분함량에는 유의적인 차이 를 보이지 않았다고 한 보고와 유사한 경향이었다. 비파가 루 첨가 설기떡(24), 자색 양파 분말 첨가 설기떡(3) 연구에 서는 부재료의 첨가량이 증가할수록 수분함량이 낮아졌다 고 보고한 반면, 살구농축액 첨가 설기떡(25)의 연구에서는 살구농축액 첨가량이 증가할수록 수분함량이 높아지는 경 향을 보고하였다.

설기떡의 $\mathrm{pH}$ 는 대조군이 6.20 으로 가장 높게 나타났고 $2 \%$ 첨가군이 $5.15,4 \%$ 첨가군이 $4.66,6 \%$ 첨가군이 4.27 로

Table 2. Moisture content, $\mathrm{pH}$ and Brix of Sulggidduk added with maquiberry powder

\begin{tabular}{ccccc}
\hline & \multicolumn{4}{c}{ Groups $^{1)}$} \\
\cline { 2 - 5 } & S- 0 & S- 2 & S-4 & S-6 \\
\hline Moisture content & $38.79 \pm 0.40^{2)}$ & $38.06 \pm 0.22$ & $37.80 \pm 1.05$ & $37.75 \pm 0.52$ \\
pH & $6.20 \pm 0.38^{\mathrm{a} 3)}$ & $5.15 \pm 0.63^{\mathrm{b}}$ & $4.66 \pm 0.01^{\mathrm{bc}}$ & $4.27 \pm 0.02^{\mathrm{c}}$ \\
${ }^{\circ}$ Brix & $0.65 \pm 0.07$ & $0.70 \pm 0.00$ & $0.70 \pm 0.01$ & $0.80 \pm 0.00$ \\
\hline
\end{tabular}

${ }^{1)}$ S-0, Sulgidduk with maquiberry powder $0 \%$; S-2, Sulgidduk with maquiberry powder 2\%; S-4, Sulgidduk with maquiberry powder 4\%; S-6, Sulgidduk with maquiberry powder $6 \%$.

${ }^{2)}$ Each value is mean $\pm \mathrm{SD}$.

${ }^{3}$ Means with different letters within a row are significantly different from each other at $p<0.05$ as determined by Duncan's multiple range test. 
마키베리 분말 첨가량이 증가할수록 감소하였는데 ( $\mathrm{p}<0.05)$, 이는 마키베리 분말의 $\mathrm{pH}$ 가 3.81로 멥쌀가루의 $\mathrm{pH}$ 5.90보다 낮기 때문인 것으로 여겨진다. 석류 농축액 첨가 설기(2), 주박 첨가 설기(26) 연구에서도 부재료의 첨 가량이 증가할수록 $\mathrm{pH}$ 가 낮아졌다고 보고하여 본 실험과 같은 경향을 보여주었다.

당도는 대조군이 $0.65^{\circ} \mathrm{Brix}$, 첨가군이 $0.70 ~ 0.80{ }^{\circ} \mathrm{Brix}$ 로 시료 간에 유의적인 차이를 보이지 않았는데, 황기 분말 첨가 설기떡(27)연구에서도 첨가량에 따라 유의적인 차이 가 없었다고 보고하여 본 실험 결과와 유사하였다.

\section{색 도}

마키베리 분말 첨가 설기떡의 색도 측정 결과는 Table 3 과 같다. 명도를 나타내는 L 값은 대조군이 79.17로 가장 높았고 $2 \%$ 첨가군 $37.52,4 \%$ 첨가군 $28.14,6 \%$ 첨가군 23.25 로 마키베리 첨가량이 증가함에 따라 유의적으로 감소하는 것으로 나타났다 $(\mathrm{p}<0.05)$. 천년초 열매 분말 첨가 설기떡 (28), 미나리 분말 첨가 설기떡(29) 연구에서도 부재료의 첨가량이 증가함에 따라 명도가 낮아지는 결과를 보고하여 본 실험의 결과와 유사하였다. 적색도를 나타내는 $\mathrm{a}$ 값은 대조군이 $0.33,2 \%$ 첨가군이 $12.03,4 \%$ 첨가군이 15.11 , $6 \%$ 첨가군이 16.10 으로 나타나 마키베리 분말 첨가량이 증가할수록 유의적으로 증가하였으며 $(\mathrm{p}<0.05)$ 이는 마키베 리의 검붉은 안토시아닌 색소가 영향을 준 것으로 여겨진 다. 토마토 분말 첨가 설기떡(30), 살구농축액 첨가 설기떡 (25)의 연구에서도 부재료 첨가량이 증가함에 따라 $\mathrm{a}$ 값이 유의적으로 증가하였다고 보고하였다.

황색도를 나타내는 b 값은 대조군이 7.80 으로 가장 높게 나타났고 마키베리 분말 첨가량이 증가할수록 감소하여 $2 \%$ 첨가군과 $4 \%$ 첨가군이 각각 -0.76 과 -1.81 을 나타내었 으며 $6 \%$ 첨가군은 -1.81 로 $4 \%$ 첨가군과 유의적인 차이를 보이지 않았다. 아로니아 분말 첨가 설기떡(5)연구와 아사 이베리 분말 첨가 설기떡(6)의 연구에서 부재료 첨가량이 증가할수록 $\mathrm{L}$ 값과 $\mathrm{b}$ 값은 감소하고 $\mathrm{a}$ 값은 증가하였다고보 고하여 유사한 색상 계열의 안토시아닌이 함유된 설기떡의

Table 3. Hunter's color value of Sulggidduk added with maquiberry powder

\begin{tabular}{ccccc}
\hline & \multicolumn{4}{c}{ Groups $^{1)}$} \\
\cline { 2 - 5 } & S-0 & S-2 & S-4 & S-6 \\
\hline L & $79.17 \pm 1.14^{2)(d 3)}$ & $37.52 \pm 1.30^{\mathrm{c}}$ & $28.14 \pm 1.47^{\mathrm{b}}$ & $23.25 \pm 0.75^{\mathrm{a}}$ \\
$\mathrm{a}$ & $0.33 \pm 0.19^{\mathrm{a}}$ & $12.03 \pm 0.14^{\mathrm{b}}$ & $15.11 \pm 0.15^{\mathrm{c}}$ & $16.10 \pm 0.35^{\mathrm{d}}$ \\
$\mathrm{b}$ & $7.80 \pm 0.13^{\mathrm{c}}$ & $-0.76 \pm 0.15^{\mathrm{b}}$ & $-1.82 \pm 0.25^{\mathrm{a}}$ & $-1.81 \pm 0.11^{\mathrm{a}}$ \\
\hline
\end{tabular}

${ }^{1)}$ S-0, Sulgidduk with maquiberry powder $0 \%$; S-2, Sulgidduk with maquiberry powder 2\%; S-4, Sulgidduk with maquiberry powder 4\%; S-6, Sulgidduk with maquiberry powder $6 \%$.

${ }^{2}$ Each value is mean $\pm \mathrm{SD}$

${ }^{3)}$ Means with different letters within a row are significantly different from each other at $\mathrm{p}<0.05$ as determined by Duncan's multiple range test.
색도값은 유사한 경향을 나타내는 것으로 나타났다.

\section{기계적 조직감}

마키베리 분말 첨가 설기떡의 조직감 특성을 측정한 결 과는 Table 4 와 같다. 단단한 정도를 나타내는 경도는 대조 군이 $177.21 \mathrm{~g} / \mathrm{cm}^{2}$ 로 가장 낮았고 첨가군은 241.16 247.68 $\mathrm{g} / \mathrm{cm}^{2}$ 로 대조군보다 높게 나타났으나 첨가군 간에 유의적 차이는 보이지 않았다( $\mathrm{p}<0.05)$. 파슬리가루 첨가 설기(31), 동결건조 가지 분말 첨가 설기떡(10)의 연구에서는 부재료 첨가량이 증가할수록 경도가 유의적으로 증가하였다고 보 고하였다. 반면에, 복분자잎 첨가 설기떡(8) 연구에서는 첨 가군의 경도가 대조군보다 낮게 나타났다고 보고하여 첨가 되는 부재료에 따라 경도 특성이 다르게 나타남을 알 수 있었다. 탄력성과 응집성은 각각 85.54 88.66\%와 72.65 $76.30 \%$ 로 나타났고 시료 간에 유의적인 차이가 없었다. 씹힘성은 경도와 같은 경향으로 대조군이 $177.96 \mathrm{~g}$ 으로 가 장 낮게 나타났고 첨가군은 $212.60 \sim 221.13 \mathrm{~g}$ 으로 시료 간 유의적인 차이를 보이지 않았으며 $(\mathrm{p}<0.05)$ 이는 화피 추출 물 첨가 설기떡(32)의 연구결과와 일치하는 경향을 보여주 었다. Kang 등(33)은 떡의 조직감 특성 중 관능성에 영향을 주는 요인으로는 일반적으로 경도, 씹힘성 등이 있고 이들 특성은 수분함량과 반비례하는 경향이 있다고 보고하였는 데 본 실험결과 시료 간 수분함량에는 유의적인 차이가 없어(Table 2) 다소 다른 경향을 나타내었다.

Table 4. Texture properties of Sulggidduk added with maquiberry powder

\begin{tabular}{ccccc}
\hline \multirow{2}{*}{$\begin{array}{c}\text { Texture } \\
\text { properties }\end{array}$} & \multicolumn{4}{c}{ Groups $^{\mathrm{l})}$} \\
\cline { 2 - 5 } & $\mathrm{S}-0$ & $\mathrm{~S}-2$ & $\mathrm{~S}-4$ & $\mathrm{~S}-6$ \\
\hline $\begin{array}{c}\text { Hardness } \\
\left(\mathrm{g} / \mathrm{cm}^{2}\right)\end{array}$ & $177.21 \pm 24.12^{2 \mathrm{bb3})}$ & $242.43 \pm 32.10^{\mathrm{a}}$ & $241.16 \pm 41.99^{\mathrm{a}}$ & $247.68 \pm 44.48^{\mathrm{a}}$ \\
$\begin{array}{c}\text { Springiness } \\
(\%)\end{array}$ & $88.66 \pm 2.71$ & $86.13 \pm 3.72$ & $85.54 \pm 2.78$ & $86.75 \pm 3.40$ \\
$\begin{array}{c}\text { Cohesiveness } \\
(\%)\end{array}$ & $76.30 \pm 4.35$ & $74.55 \pm 4.66$ & $72.82 \pm 4.04$ & $72.65 \pm 3.56$ \\
$\begin{array}{c}\text { Chewiness } \\
(\mathrm{g})\end{array}$ & $177.96 \pm 18.86^{\mathrm{b}}$ & $221.13 \pm 26.15^{\mathrm{a}}$ & $212.60 \pm 32.15^{\mathrm{a}}$ & $220.07 \pm 39.55^{\mathrm{a}}$ \\
\hline
\end{tabular}

${ }^{11}$ S-0, Sulgidduk with maquiberry powder 0\%; S-2, Sulgidduk with maquiberry powder $2 \%$; S-4, Sulgidduk with maquiberry powder 4\%; S-6, Sulgidduk with maquiberry powder $6 \%$.

${ }^{2}$ Each value is mean $\pm \mathrm{SD}$.

${ }^{3)}$ Means with different letters within a row are significantly different from each other at $\mathrm{p}<0.05$ as determined by Duncan's multiple range test.

\section{기호도 조사}

마키베리 분말 첨가 설기떡의 기호도 조사 결과는 Table 5 와 같다. 표면색은 대조군이 5.58 점으로 평가되었고 $2 \%$ 첨가군이 4.25 점으로 가장 낮은 점수로 평가된 반면, $4 \%$ 와 $6 \%$ 는 각각 5.58 점과 5.67점으로 대조군과 유의적인 차이 없이 평가되었다(p<0.05). 냄새는 4.33 5.42점, 맛은 4.92 
5.83점, 전체적인 기호도는 5.25 5.92점으로 모든 시료 간 에 유의적 차이가 없는 것으로 나타나 마키베리의 첨가가 설기떡의 기호도에 크게 영향을 미치지 않음을 알 수 있었 다. 이상의 결과를 종합하여 볼 때 마키베리를 $6 \%$ 까지 첨가 하여도 관능성에는 크게 영향을 미치지 않을 것으로 여겨 진다.

Table 5. Consumer acceptance test of Sulggidduk added with maquiberry powder

\begin{tabular}{ccccc}
\hline & \multicolumn{4}{c}{ Group $^{1)}$} \\
\cline { 2 - 5 } & $\mathrm{S}-0$ & $\mathrm{~S}-2$ & $\mathrm{~S}-4$ & $\mathrm{~S}-6$ \\
\hline Surface color & $5.58 \pm 0.99^{2) \mathrm{b3})}$ & $4.25 \pm 1.54^{\mathrm{a}}$ & $5.58 \pm 1.24^{\mathrm{b}}$ & $5.67 \pm 1.55^{\mathrm{b}}$ \\
Smell & $5.42 \pm 1.16$ & $4.92 \pm 1.56$ & $4.67 \pm 1.07$ & $4.33 \pm 0.98$ \\
Taste & $5.83 \pm 1.11$ & $5.25 \pm 0.96$ & $4.92 \pm 0.79$ & $4.92 \pm 1.44$ \\
Overall acceptability & $5.92 \pm 1.08$ & $5.25 \pm 1.28$ & $5.50 \pm 0.90$ & $5.25 \pm 1.21$ \\
\hline
\end{tabular}

${ }^{1)}$ S-0, Sulgidduk with maquiberry powder 0\%; S-2, Sulgidduk with maquiberry powder 2\%; S-4, Sulgidduk with maquiberry powder 4\%; S-6, Sulgidduk with maquiberry powder $6 \%$.

${ }^{2)}$ Each value is mean $\pm S D$.

${ }^{3}$ Means with different letters within a row are significantly different from each other at $p<0.05$ as determined by Duncan's multiple range test.

\section{총 폴리페놀 및 총 안토시아닌 함량 측정}

마키베리 분말 첨가 설기떡의 총 폴리페놀 함량 및 총 안토시아닌 함량 측정 결과는 Table 6과 같다. 총 폴리페놀 은 대조군이 $8.66 \mathrm{mg} \mathrm{GAE} / 100 \mathrm{~g}$ 으로 가장 낮게 나타났고 첨가군은 76.98 262.71 mg GAE/100 g으로 마키베리 분말 첨가량이 증가할수록 유의적으로 증가하였다 $(\mathrm{p}<0.05)$. 총 안토시아닌 함량은 대조군이 $0.02 \mathrm{mg} \mathrm{C} 3 \mathrm{G} / 100 \mathrm{~g}$ 으로 거의 검출되지 않았고, 첨가군은 $9.76 ~ 31.19 \mathrm{mg} \mathrm{C} 3 \mathrm{G} / 100 \mathrm{~g}$ 으로 마키베리 분말 첨가량이 증가할수록 증가하여 $6 \%$ 첨가군 에서 가장 높게 나타나 $(\mathrm{p}<0.05)$ 총 폴리페놀 함량에서와 같은 경향을 나타내었다. Hwang과 $\operatorname{Hwang}(5)$ 은 아로니아 분말 첨가 설기떡의 안토시아닌 함량이 $11.7 \sim 58.4 \mathrm{mg}$ $\mathrm{C} 3 \mathrm{G} / 100 \mathrm{~g}$ 으로 나타났고 아로니아 분말 첨가량 증가에 따 라 증가하였다고 보고하여 본 실험의 결과와 유사하였다.

Table 6. Total polyphenol and total anthocyanin contents of Sulggidduk added with maquiberry powder

\begin{tabular}{lcccc}
\hline & \multicolumn{4}{c}{ Groups $^{1)}$} \\
\cline { 2 - 5 } & $\mathrm{S}-0$ & $\mathrm{~S}-2$ & $\mathrm{~S}-4$ & $\mathrm{~S}-6$ \\
\hline $\begin{array}{l}\text { Total polyphenol } \\
\text { (mg GAE/100 g) }\end{array}$ & $8.66 \pm 1.35^{2 \mathrm{2} 3)}$ & $76.98 \pm 2.72^{\mathrm{b}}$ & $159.74 \pm 13.61^{\mathrm{c}}$ & $262.71 \pm 14.97^{\mathrm{d}}$ \\
$\begin{array}{c}\text { Total anthocyanin } \\
\text { (mg C3G/100 g) }\end{array}$ & $0.02 \pm 0.00^{\mathrm{a}}$ & $9.76 \pm 0.28^{\mathrm{b}}$ & $20.59 \pm 0.14^{\mathrm{c}}$ & $31.19 \pm 1.39^{\mathrm{d}}$ \\
\hline
\end{tabular}

${ }^{1)} \mathrm{S}-0$, Sulgidduk with maquiberry powder 0\%; S-2, Sulgidduk with maquiberry powder 2\%; S-4, Sulgidduk with maquiberry powder 4\%; S-6, Sulgidduk with maquiberry powder $6 \%$.

${ }^{2)}$ Each value is mean $\pm \mathrm{SD}$.

${ }^{3)}$ Means with different letters within a row are significantly different from each other at $\mathrm{p}<0.05$ as determined by Duncan's multiple range test.
마키베리에는 phenolic acid, quercetin, myricetin, catechin, 안토시아닌 등의 폴리페놀이 존재하며 마키베리의 안토시 아닌은 74\% 이상이 delphinidin으로 delphinidin 3-O-sambubioside, delphinidin 3,5-O-diglucoside, delphinidin 3-O-sambubioside5-O-glucoside 등의 성분이 강력한 항산화 작용을 하는 것으 로 보고되고 있다 $(2,34)$.

\section{항산화 활성 측정}

마키베리 분말 첨가 설기떡의 DPPH radical 소거능 측정 결과는 Fig. 1과 같다. 대조군이 $20.52 \%$ 로 가장 낮았고 마키 베리 분말 첨가량이 증가할수록 증가하여 $2 \%$ 첨가군은 $55.10 \%, 4 \%$ 첨가군은 $88.10 \%$ 를 나타내었으며 $6 \%$ 첨가군 은 $94.67 \%$ 로 $4 \%$ 첨가군과 유의적인 차이가 없었다 (p<0.05). DPPH는 짙은 보라색을 띠는 free radical로서 항산 화 물질로부터 전자나 수소를 제공받으면 환원되면서 노란 색으로 탈색되는 원리를 이용하여 항산화능 측정에 많이 이용되고 있고(35) 색이 엷어지는 정도가 클수록 소거능이 큰 것을 의미한다. 석류 농축액 첨가 설기떡(2), 가지 분말 첨가 설기떡(10), 아스파라거스 첨가 설기떡(4)의 연구에서 도 부재료 첨가량이 증가할수록 $\mathrm{DPPH}$ radical 소거능이 증가하였다고 보고하여 본 실험의 결과와 일치하였다.

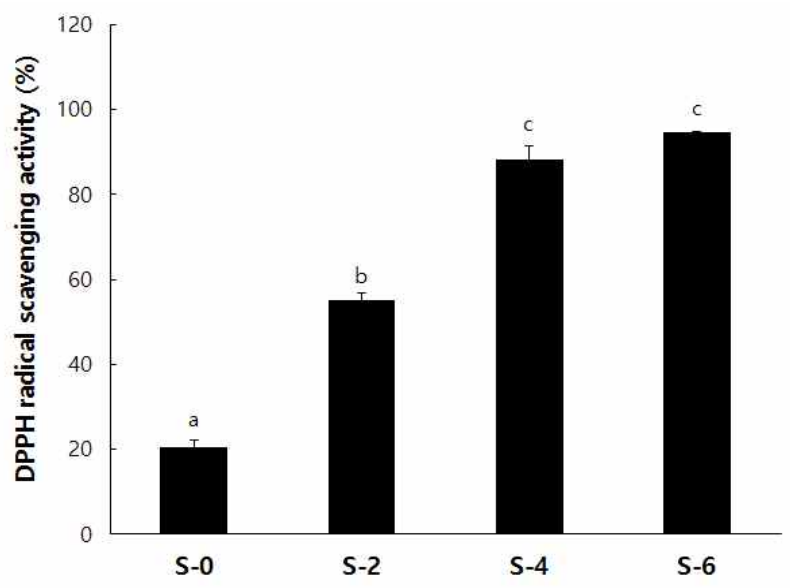

Fig. 1. DPPH radical scavenging activity of Sulggidduk added with maquiberry powder.

S-0, Sulgidduk with maquiberry powder $0 \%$; S-2, Sulgidduk with maquiberry powder 2\%; S-4, Sulgidduk with maquiberry powder 4\%; S-6, Sulgidduk with maquiberry powder $6 \%$.

Values with different letters $(\mathrm{a}-\mathrm{d})$ are significantly different at $\mathrm{p}<0.05$

마키베리 분말 첨가 설기떡의 ABTS radical 소거능은 Fig. 2에 나타난 바와 같이 대조군이 $6.75 \%$, 첨가군이 43.63 96.34\%로 마키베리 분말 첨가량 증가에 따라 유의적 으로 증가하였다. ABTS radical 소거능은 시료 중에 항산화 활성을 갖는 물질이 존재하면 청록색의 ABTS cation radical $\left(\mathrm{ABTS}{ }^{\circ}{ }^{\dagger}\right.$ )이 소거되면서 탈색되는 원리를 이용하여 측정하 는 방법이다(36). Choi와 $\operatorname{Kim}(37)$ 의 모링가 잎 추출물 첨가 설기떡 연구와 Shin 등(38)의 흑마늘 추출물 첨가 설기떡 
연구에서도 부재료 첨가량이 증가할수록 $\mathrm{ABTS}$ radical 소 거능이 유의적으로 증가하였다고 보고하였다. 본 실험 결 과 마키베리 분말 첨가 설기떡이 대조군보다 높은 항산화 활성을 보인 것은 마키베리에 함유되어 있는 폴리페놀 및 안토시아닌 함량과 상관이 있는 것으로 추측된다.

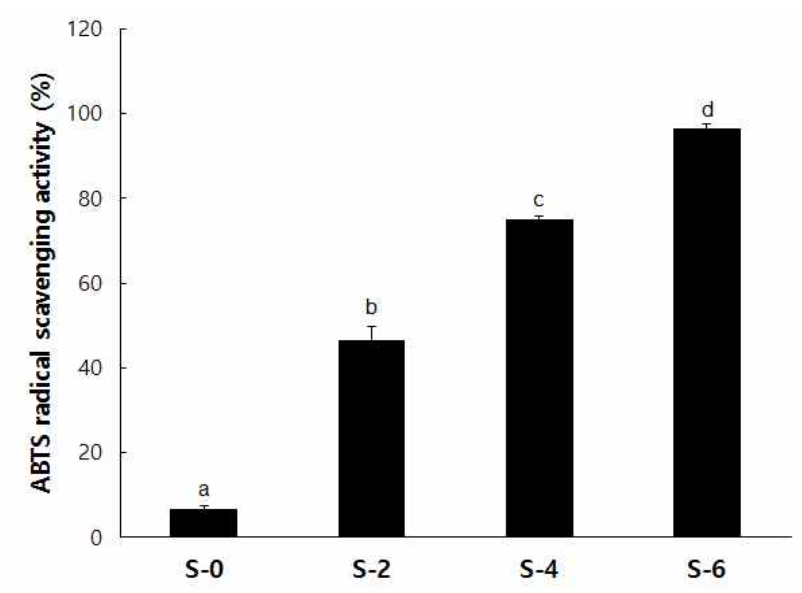

Fig. 2. ABTS radical scavenging activity of Sulggidduk added with maquiberry powder.

S-0, Sulgidduk with maquiberry powder $0 \%$; S-2, Sulgidduk with maquiberty powder 2\%; S-4, Sulgidduk with maquiberry powder 4\%; S-6, Sulgidduk with maquiberry powder $6 \%$.

Values with different letters $(\mathrm{a}-\mathrm{d})$ are significantly different at $\mathrm{p}<0.05$.

마키베리 분말 첨가 설기떡의 환원력 측정결과는 Fig. 3 에 나타나 바와 같다. 대조군은 0.03 (Abs)으로 활성이 거의 없었으며 마키베리 분말 첨가량이 증가할수록 증가하 여 $2 \%$ 첨가군 $0.29(\mathrm{Abs}), 4 \%$ 첨가군 $0.45(\mathrm{Abs})$ 으로 나타났 고 그 이후 급격히 증가하여 $6 \%$ 첨가군은 $1.20(\mathrm{Abs})$ 으로 가장 높게 나타났다( $<<0.05)$. 환원력은 항산화 활성과 밀접

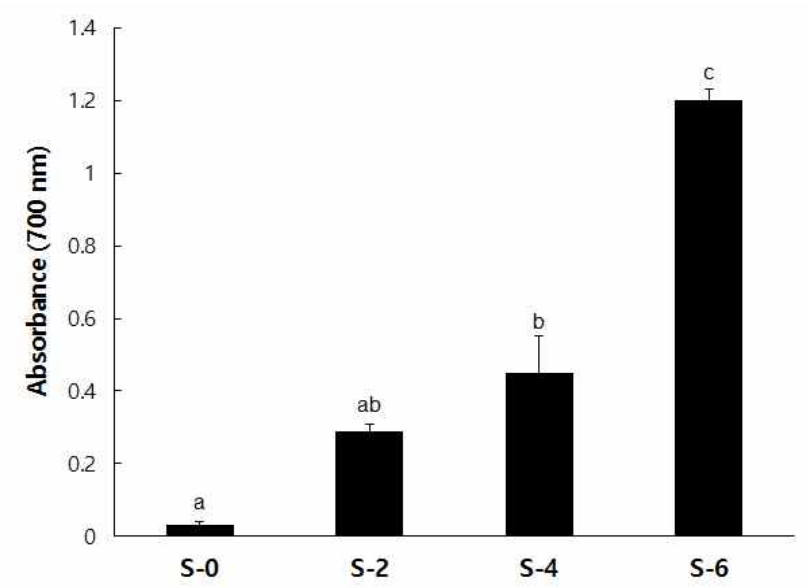

Fig. 3. Reducing power of Sulggidduk added with maquiberry powder.

S-0, Sulgidduk with maquiberry powder $0 \%$; S-2, Sulgidduk with maquiberry powder $2 \%$; S-4, Sulgidduk with maquiberry powder 4\%; S-6, Sulgidduk with maquiberry powder $6 \%$.

Values with different letters $(a-c)$ are significantly different at $p<0.05$.
한 관계가 있어서 시료 추출물 중에 항산화물질이 존재하면 ferric ion $\left(\mathrm{Fe}^{3+}\right)$ 을 ferrous ion $\left(\mathrm{Fe}^{2+}\right)$ 으로 환원시키면서 푸른 색을 띠게 되는데 발색정도가 높을수록 높은 환원력을 나타 낸다(39). 본 실험 결과 마키베리 분말은 ferric ion을 효과적 으로 환원시키는 것으로 나타났는데 이는 마키베리에 함유 된 폴리페놀 및 안토시아닌 함량과 관련이 큰 것으로 여겨 진다. $\mathrm{Joo}(32)$ 의 화피추출물 첨가 설기떡 연구와 Park 등(40) 의 모시풀잎 분말 첨가 설기떡 연구에서도 부재료 첨가량이 증가할수록 환원력은 유의적으로 증가하였다고 보고하여 본 실험과 유사하였다. 이로써 마키베리 분말을 첨가하여 제조한 설기떡은 찌는 과정을 통하여 열처리를 하였음에도 높은 항산화 활성을 나타냄으로써 기능성 떡으로서의 상품 화 가능성이 있음을 보여주었다.

\section{요 약}

본 연구에서는 마키베리 분말을 여러 수준 $(0 \%, 2 \%, 4 \%$, $6 \%$ )으로 첨가하여 설기떡을 제조하고 수분함량, $\mathrm{pH}$, 당도, 색도, 조직감, 기호도, 항산화 활성 등을 측정하였다. 수분 함량은 $37.75 ~ 38.79 \%$ 로 모든 시료 간에 유의적인 차이가 없었고 $\mathrm{pH}$ 는 대조군이 6.20으로 가장 높게 나타났고 첨가 군이 4.27 5.15로 마키베리 분말 첨가량이 증가할수록 감소 하는 것으로 나타났다. 당도는 $0.65 \sim 0.80{ }^{\circ} \mathrm{Brix}$ 로 나타났고 시료 간에 유의적인 차이가 없었다. 색도 측정 결과 명도를 나타내는 $\mathrm{L}$ 값은 마키베리 첨가량이 증가함에 따라 유의적 으로 감소하였고 적색도를 나타내는 a 값은 유의적으로 증가하였다. 황색도를 나타내는 $\mathrm{b}$ 값은 대조군이 가장 높게 나타났고 첨가군은 (-)값을 나타내었다. 경도와 씸힘성은 대조군이 첨가군보다 낮았고 첨가군 간에는 유의적인 차이 를 보이지 않았다. 기호도 조사 결과 표면색은 $2 \%$ 첨가군이 가장 낮은 점수로 평가된 반면, $4 \%$ 첨가군과 $6 \%$ 첨가군은 대조군과 유의적인 차이 없이 평가되었다. 냄새, 맛, 전체적 인 기호도는 시료 간에 유의적인 차이가 없는 것으로 나타 났다. 마키베리 분말 첨가 설기떡의 총 폴리페놀 함량은 대조군이 $8.66 \mathrm{mg} \mathrm{GAE} / 100 \mathrm{~g}$ 으로 가장 낮게 나타났고 첨가 군은 76.98 262.71 mg GAE/100 g으로 마키베리 분말 첨가 량이 증가할수록 유의적으로 증가하였다. 총 안토시아닌 함량은 첨가군이 9.76 31.19 mg C3G/100 g으로 $6 \%$ 첨가군 에서 가장 높게 나타났다. 마키베리 분말 첨가 설기떡의 항산화 활성을 측정한 결과 DPPH radical 소거능, $\mathrm{ABTS}$ radical 소거능, 환원력 모두 대조군이 가장 낮았고 마키베 리 분말 첨가량이 증가할수록 증가하는 것으로 나타났으며 이는 마키베리 분말에 함유되어 있는 폴리페놀 및 안토시아 닌 함량과 상관성이 있는 것으로 여겨진다.

본 실험에서 마키베리 분말 첨가 설기떡의 항산화 활성 과 관능성을 모두 고려하여 볼 때 마키베리 분말을 $6 \%$ 까지 
첨가하여도 좋을 것으로 여겨지며 향후 기능성 떡으로서의 상품화 가능성이 있을 것으로 기대된다.

\section{References}

1. Yoon SJ (2001) Korean traditional desserts. Ji-gu Publishing Co., Seoul, Korea, p 11-12, 26

2. Choi JE, Lee JH (2015) Selected physicochemical and consumer preference characteristics of Baikseolgi with pomegranate concentrate. J Korean Soc Food Sci Nutr, 44, 160-164

3. Hwang SJ (2013) Quality characteristics of korean steamed rice cake containing different amount of red onion powder. Korean J Food Preserv, 20, 488-494

4. Jang YY, Kim JH, Song KY, O HB, Kim YS (2016) Quality characteristics and antioxidant activities of Sulgidduck with asparagus (Asparagus officinalis L.) powder. J East Asian Soc Dietary Life, 26, 63-72

5. Hwang YR, Hwang ES (2015) Quality characteristics and antioxidant activity of Sulgidduk by the addition of aronia powder (Aronia melanocarpa). Korean J Food Sci Technol, 47, 452-459

6. Choi YS (2015) The study of quality characteristics of acaiberry (Euterpe oleracea Mart.) powder Sulgidduk Korean J Culinary Res, 21, 90-99

7. Seo KM, Chung YH (2014) Quality characteristics of Sulgidduk added with turmeric powder. J East Asian Soc Dietary Life, 24, 201-207

8. Rha YA, Kang BN (2014) Quality evaluation of Sulgidduk added with rubus coreanus miquel leaf powder. Korean J Culinary Res, 20, 128-135

9. Yoo SS, Ko SH (2014) Quality characteristics of Sulgidduk with beet leaf powder. Korean J Food Cook Sci, 30, 119-128

10. Choi SH, Moon SJ, Lee MK, Ahn JS (2013) Quality characteristics of Sulgidduk prepared with added freeze dried-eggplant powder. Korean J Food \& Nutr, 26, 421-427

11. Kim CH, Seok HM (2015) Analysis of consumption pattern and plan for reaction of blueberry market. Paper presented at 2015 Summer Meeting of Korean Society of Food Marketing Association, August 27-28, Jecheon, Korea

12. Schreckinger ME, Wang J, Yousef G, Lila MA, Gonzalez de Mejia E (2010) Antioxidant capacity and in vitro inhibition of adipogenesis and inflammation by phenolic extracts of Vaccinium floribundum and Aristotelia chilensis. J Agric Food Chem, 58, 8966-8976

13. Brauch JE, Buchweitz M, Schweiggert RM, Carle R (2016) Detailed analyses of fresh and dried maqui (Aristotelia chilensis (Mol.) Stuntz) berries and juice. Food Chem, 190, 308-316

14. Rojo LE, Ribnicky D, Logendra S, Poulev A, Rojas-Silva P, Kuhn P, Dorn R, Grace MH, Lila MA, Raskin I (2012) In vitro and in vivo anti-diabetic effects of anthocyanins from maqui berry (Aristotelia chilensis). Food Chem, 131, 387-396

15. Molgaard P, Holler JG, Asar B, Liberna I, Rosenbak LB, Jebjerg CP, Jorgensen L, Lauritzen J, Guzman A, Adsersen A, Simonsen HT (2011) Antimicrobial evaluation of Huilliche plant medicine used to treat wounds. J Ethnopharm, 138, 219-227

16. Cho NS, Chung HJ (2016) Quality characteristics of Sulgidduk added with maquiberry powder. MS Report, Daejin University, Korea, p 6

17. AOAC (1980) Official methods of analysis. 13th ed. Association of Official Analytical Chemists, Washington $\mathrm{DC}, \mathrm{p} 31$

18. Dewanto V, Wu X, Liu RH (2002) Processed sweet corn has higher antioxidant activity. J Agric Food Chem, 50, 4959-4964

19. Lee J, Durst RW, Wrolstad RE (2005) Determination of total monomeric anthocyanin pigment content of fruit juices, beverages, natural colorants, and wines by the $\mathrm{pH}$ differential method: Collaborative Study. J AOAC Int, 88, 1269-1278

20. Blois MS (1958) Antioxidant determinations by the use of a stable free radical. Nature, 181, 1199-1200

21. Re R, Pellegrini N, Proteggente A, Pannala A, Yang M, Rice-Evans C (1999) Antioxidant activity applying an improved ABTS radical cation decolorization assay. Free Radic Biol Med, 26, 1231-1237

22. Wong JY, Chye FY (2009) Antioxidant properties of selected tropical wild edible mushrooms. J Food Compos Anal, 22, 269-277

23. Park KS, Jang JO, Yoon HK, Kim HR (2010) The quality characteristics of Sulgidduk added with Cheongkukjang powder. Korean J Culinary Res, 16, 250-258

24. Kang YS (2014) Quality characteristics of Seolgidduk added with Loquat fruit powder. J East Asian Soc Dietary Life 24, 785-792

25. Choi WS, Chae KY (2012) Quality characteristics of Sulgidduk by the addition of apricot paste. Korean J Food 
Cookery Sci, 28, 695-701

26. Cho YH, Cho JS, Kim JY, Kim US, Choi JH, Park JH (2013) Quality characteristics of Sulgidduk with Makgeolli Lees. J East Asian Soc Dietary Life, 23, 227-233

27. Lee SH, Cho SH (2013) Quality characteristics of Sulgidduk added with Astragalus membranaceus powder. Korean J Food Cookery Sci, 29, 233-239

28. Jang SY, Kim MH, Hong G (2013) Quality changes of Sulgidduk added cheonnyuncho (Oputia humifusa) fruit powder during storage. Korean J Food Cookery Sci, 29, 501-509

29. Sung KH, Hong JS, Seo BH, Choi JJ (2010) A study of the quality characteristics of Sulgidduk added with Dropwort Oenanthe ja vanica D.C. powder. J East Asian Soc Dietary Life, 20, 589-595

30. Kim MY, Chun SS (2008) Quality characteristics of Sulgidduk with tomato powder. Korean J Food Cookery Sci, 24, 412-418

31. Lim JH, Park JH (2011) The quality characteristics of Sulgidduk prepared with parsley powder. Korean J Food Cookery Sci, 27, 101-111

32. Joo SY (2013) Antioxidant activity and quality characteristics of Sulgidduk prepared with Prunus yedoensis matsumura extract. Korean J Food Cookery Sci, 29, 115-122

33. Kang HJ, Lee JK, Lim JK (2012) Quality characteristics of Topokki Garaedduk with different moisture ratios. J Korean Soc Food Sci Nutr, 41, 561-565
34. Woodward G, Kroon P, Cassidy A, Kay C (2009) Anthocyanin stability and recovery: implications for the analysis of clinical and experimental samples. J Agric Food Chem, 57, 5271-5278

35. Kim MJ, Park EJ (2011) Feature analysis of different in vitro antioxidant capacity assays and their application to fruit and vegetable samples. J Korean Soc Food Sci Nutr, 40, 1053-1062

36. Benzie IFF, Strain JJ (1996) The ferric reducing ability of plasma as a measure of "antioxidant power": the FRAP assay. Anal Biochem, 239, 70-76

37. Choi EJ, Kim EK (2015) Antioxidation, physicochemical, and sensory characteristics of Sulgidduck fortified with water extracts from Moringa oleifera leaf. Korean J Food Cook Sci, 31, 335-343

38. Shin JH, Kim YA, Kang MJ, Yang SM, Sung NJ (2010) Preparation and characteristics of Sulgidduk containing different amounts of black garlic extract. Korean J Food Cookery Sci, 26, 559-566

39. Terpinc P, Ceh B, Ulrih, NP, Abramovic H (2012) Studies of the correlation between antioxidant properties and the total phenolic content of different oil cake extracts. Ind Crops Prod, 39, 210-217

40. Park SS, Kim SI, Sim KH (2011) The quality characteristics and antioxidative activity of Sulgidduk supplemented with ramie leaf powder. Korean J Food Cookery Sci, 27, 763-772 